\title{
Envisaging the Needs for Designing L2 Pronunciation Assessment
}

\author{
Widya Ratna Kusumaningrum ${ }^{1}$, Candradewi Wahyu Anggraeni², Rangga Asmara ${ }^{3}$ \\ $\left\{\right.$ kusumaningrum@untidar.ac.id ${ }^{1}$, candradewi@untidar.ac.id ${ }^{2}$, asmara@untidar.ac.id $\left.^{3}\right\}$ \\ ${ }^{1,2}$ Universitas Tidar, Magelang, Indonesia
}

\begin{abstract}
The study aims to discuss the need analysis for understanding the EFL teachers and learners voices towards the integration technology to evaluate and assess their L2 pronunciation. This study was the preliminary study of the design-based research of the O'Speak version 1.0. The O'Speak version 1.0 is an android-based speaking test which has been developing for over six months. The O'Speak integrated the Feuerstein's Mediated Language Experience principles into the L2 testing. It is designed to respond to the local need of a speaking test which facilitates and helps teachers/lecturers to see the learners' speaking abilities in the EFL context. In this initial stage development of $\mathrm{O}$ 'Speak, this study was investigated under descriptive qualitative with three instruments used: observation and closed-ended questionnaire. These data were then analyzed used SPSS 25. Drawing on a series of analyses, the study has a major finding. This study urges the development of a tool to assess EFL learners' pronunciation ability. The developed tool should be integrated technology. In this context, a tool is proposed to have significances in their learnings.
\end{abstract}

Keywords: design-based research, O‘speak, online speaking test, Feuerstein's mediated language experience, analysis of practical problems

\section{INTRODUCTION}

The most recent trend in language learning is the deployment of technology to aid the teaching-learning process. Some terminologies have been initiated as the integration of technology in language learning such as TELL (Technology Enhanced Language Learning) and MALL (Mobile-Assisted Language Learning). This movement stresses continuous and spontaneous learning principles and enables language learners to study in any situations and contexts [1] [2]. Although technology has been widely used in a language learning context, its practice as an evaluation tool has not been considered extensively. As an integrative part of language teaching and learning, the use of technology to deliver language tests in any settings is in an early stage [3].

The chronological order of the development of computerizing language testing might be traced with the introduction a computer-based version of TOEFL (CBT) in 1998, and internetbased testing (iBT) in the USA, Canada, France, Germany, and Italy in late 2005 [4] [5] as the placement form of a pencil-paper test. However, the technology trend for language assessment is mostly for the licensed and professional purposes.

For decades, the domain of assessing a language has been rotating around the evaluation of grammatical competence. However, the emergence of assessing communicative 
competence has been attracting researchers and linguistics [6] [7] [8]. In assessing this communicative competence, teachers undertake the face-to-face procedure and use the constructed benchmarks for assessing language performance including role-playing [9] and monolog. The issue arises on how the rubrics address and detect the subjective assessment of spoken language [10] [11] and how they help teachers or raters to construe meanings of the score.

This paper discusses the need analysis for understanding the voices towards the integration technology to evaluate and assess their L2 pronunciation. This study is the initial stage for designing $\mathrm{O}^{\prime}$ Speak version 1.0 to test one micro skill in communicative competence. O'Speak is a mobile-based test assessing pronunciation. O'Speak is developed within the Feuerstein's Mediated Learning Experience framework [12]. This framework presents an option to the parametric and static form of language testing. Feuerstein's Mediated Learning Experience framework stresses the idea that intelligence is modifiable. It deals with a process to build brain capability and to promote intellectual growth through deeper learning [13]-[15]. The application of Mediated Learning Experience is to envisage an effective learning process and to promote effective interaction between learners and environment through the systematic, experiential and structural exposure as provided by a mediator [16] [17]. At this case, classroom teachers play roles as mediators to facilitate a child's cognitive development. In applying the MLE process, a child undergoes an integrated procedure of modifying intervention or interaction [18]. This study tries to integrate three ideas on how to utilize technology to assess pronunciation as one of the speaking micro-skills and its implications for learners' language development. This study was the initial stage of design-based research. The endmost process would be discussed in the next publication. Thus, this study addresses a research question on the practical problem analysis of the development of O'Speak version 1.0 .

RQ1. What are the EFL teachers and learners' needs for designing L2 pronunciation assessment?

\section{METHOD}

To answer the investigated research question, this study was investigated under the Reeves' design-based research (DBR) method [19]. DBR provides extensive report and explanation on the entire design process [20] of the proposed O'Speak version 1.0. This paper narrated the initial step of four focal DBR stages (1) analysis of practical problems in communicative competence, while (2) development of the model by adapting Feuerstein's Mediated Learning Experience framework in the O'Speak version 1.0 design, (3) the iterative cycle of testing, (4) and reflection stages will be reported later.

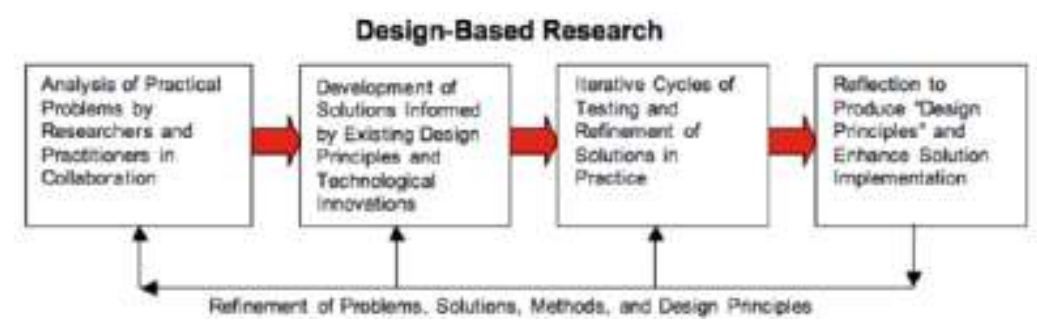

Figure 1. Reeves' Design-Based Research (2006) 
The practical problems analysis was done by collecting information from parties who may have direct problems with assessing communicative competences such as university lecturers and the students. This need analysis was done by observing and giving close-ended questionnaires. The observation used Heflin, Shewmaker, Nguyen's classroom behavioral observation [21]. This observation sheet focuses on the impact of mobile technology with three focal observed indicators on students' attitude, engagement, and learning. This adaptable observation sheet was refined into the Likert-scale ranged from 0 to 5 .

The questionnaire was adapted from Coskun (age, gender, and contact with native or non-native speakers) and secondly, attitudes towards pronunciation and accent-related matters. The second part of the questionnaire has eight indicators such as accent preferences, goals of pronunciation teaching, native non-native varieties, students' awareness, teacher's pronunciation exemplary, exposure and tolerance to the native pronunciation, and listening preferences [22]. This study involved 65 EFL learners and two EFL phonology teachers to participate in the need analysis.

\begin{tabular}{lc} 
Table 1. Demographic information about the respondent \\
\hline Age & 16 \\
Below 20 & 49 \\
After 20 & \\
\hline Gender & 24 \\
Male & 41 \\
Female & \\
\hline College Admission Year & 14 \\
Freshman & 27 \\
Sophomore & 17 \\
Junior & 7 \\
Senior &
\end{tabular}

In analyzing the observation data, we deployed the descriptive qualitative focusing on the addressed indicators that had been used. We depicted each indicator with the examples. The closed-ended questionnaire data were coded based on the indicators and analyzed using SPSS 25 .

\section{RESULT AND DISCUSSION}

In designing the O'Speak version 1.0 which emphasized on the Feuerstein's Mediated Learning Experience framework [12] to test pronunciation as one of micro-skill in communicative competences, this study adopted the first stage of Reeves' design-based research (DBR) method [19]. Stage 1 of the development was analyzing the practical problems for pronunciation assessment based on the observation and questionnaire data. The observation exhibited that students' attitude, engagement, and learning in utilizing technology were relatively low.

Table 2. Heflin, Shewmaker, Nguyen's classroom behavioral observation (2017).

\begin{tabular}{ll}
\hline indicators & \\
\hline attitude & $43.65 \%$ \\
\hline engagement & $41.21 \%$ \\
\hline learning & $38.54 \%$ \\
\hline
\end{tabular}


It can be interpreted from table 2 that the students' attitudes towards technology were negative with $43.65 \%$. It depicted that students were not self-confident and convinced that technology would have direct implication for the learning activities. Those who were familiar with the application might have better concentration and focus on the task rather than settling with how to operate the technology. Another indicator as shown is students' engagement. The students' engagement is an important foundation for learning that benefitted students through active classroom participation. It deals with the students' involvement and active participation in learning activities. As shown in table 2, the participation and the engagement students in utilizing technology were low with $41.21 \%$. Students' engagement was relatively low since it may be affected by the students' attitudes towards the used technology. Thus, it has a direct impact on students' learning. The learning situation was dominated with the anxiety on how to operate the technology and students had little intention on the learning activities.

In stage 1, the study involves Coskun's questionnaire investigating accent preferences, goals of pronunciation teaching, native non-native varieties, students' awareness, teacher's pronunciation exemplary, exposure and tolerance to the native pronunciation, and listening preferences [22]. The first component was the personal accent preference (table 3) and reasons for selecting certain English accents (table 4).

Table 3. Accent adopted while speaking

\begin{tabular}{|c|c|c|c|c|c|}
\hline & 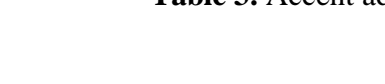 & Frequency & Percent & $\begin{array}{c}\text { Valid } \\
\text { Percent }\end{array}$ & $\begin{array}{c}\text { Cumulative } \\
\text { Percent }\end{array}$ \\
\hline \multirow[t]{4}{*}{ Valid } & Standard British English & 2 & 3.0 & 3.1 & 3.1 \\
\hline & Standard American English & 2 & 3.0 & 3.1 & 6.2 \\
\hline & A type of Indonesian-English & 61 & 91.0 & 93.8 & 100.0 \\
\hline & Total & 65 & 97.0 & 100.0 & \\
\hline Missing & System & 2 & 3.0 & & \\
\hline Total & & 67 & 100.0 & & \\
\hline
\end{tabular}

Table 3 depicted how students were convenient speaking English in their native accent of Indonesian-English $(\mathrm{N}=61 ; 93.8 \%)$. The minimum use of standard British English $(\mathrm{N}=2$; $3.1 \%)$ and standard American English $(\mathrm{N}=2 ; 3.1 \%)$ were the impacts of their negative attitude and anxiety towards the accent. As they argue, it was not easy to adapt and pronounce the standard British English and standard American English.

Table 4. Reasons for selecting certain English accents

\begin{tabular}{ll|r|r|r|r} 
& \multicolumn{2}{c}{ Table 4. Reasons for selecting certain English accents } & \multicolumn{1}{c}{ Valid } & Cumulative \\
& & Frequency & Percent & Percent & Percent \\
\hline Valid & Identification & 9 & 13.4 & 13.8 & 13.8 \\
\cline { 2 - 6 } & It sounds best & 4 & 6.0 & 6.2 & 20.0 \\
\cline { 2 - 6 } & Family background & 52 & 77.6 & 80.0 & 100.0 \\
\cline { 2 - 6 } & Total & 65 & 97.0 & 100.0 & \\
\hline Missing & System & 2 & 3.0 & & \\
\hline Total & & 67 & 100.0 & & \\
\hline
\end{tabular}

Table 4 describes how participants select the native Indonesian accent while speaking English. The prominent reason was affected by the family background that has direct influence to the development of strong native accent $(\mathrm{N}=52 ; 80 \%)$ in comparison with the identification $(\mathrm{N}=9 ; 13.8 \%)$ and it sounds best $(\mathrm{N}=4 ; 6.2 \%)$. The reasons as shown in table 4 
are in line with the number of daily activity outside of the classroom and the exposure to native/non-native English pronunciation (table 5 and table 6).

Table 5. Exposure to different varieties of English

\begin{tabular}{|c|c|c|c|c|c|}
\hline & & Frequency & Percent & $\begin{array}{l}\text { Valid } \\
\text { Percent }\end{array}$ & $\begin{array}{l}\text { Cumulative } \\
\text { Percent }\end{array}$ \\
\hline \multirow[t]{3}{*}{ Valid } & Yes & 4 & 6.0 & 6.2 & 6.2 \\
\hline & No & 61 & 91.0 & 93.8 & 100.0 \\
\hline & Total & 65 & 97.0 & 100.0 & \\
\hline Missing & System & 2 & 3.0 & & \\
\hline \multicolumn{2}{|c|}{ Total } & 67 & 100.0 & & \\
\hline
\end{tabular}

Table 5 indicates that students have minimum exposure to different varieties of English $(\mathrm{N}=61,93.8 \%)$. Even with the development of the YouTube platform or other social media in the industrial era 4.0, students do not use the platform and social platform effectively. YouTube platform may be beneficial for learning if they watch English movies, talk shows, and TV news rather using it to watch non-English programs. Some social media such as Instagram and Facebook are used to link them with their acquaintances rather than to build the international friendship around the world.

Table 6. Exposure and tolerance to the native pronunciation

\begin{tabular}{ll|r|r|r|r}
\hline Table 6. Exposure and tolerance to the native pronunciation \\
& & & Valid & Cumulative \\
& Frequency & Percent & Percent & Percent \\
\hline Valid & Yes & 61 & 91.0 & 93.8 & 100.0 \\
\cline { 2 - 5 } & No & 4 & 6.0 & 6.2 & 6.2 \\
\cline { 2 - 4 } & Total & 65 & 97.0 & 100.0 & \\
\hline Missing & System & 2 & 3.0 & & \\
\hline Total & & 67 & 100.0 & & \\
\hline
\end{tabular}

Table 6 shows a typical condition with table 5 , in this condition, students were tolerant of the native pronunciation $(\mathrm{N}=61 ; 93.8 \%)$ for the communication goals between non-native speakers. Although most students were pleased to speak the type of Indonesian-English, they showed their preferences to know more the standard of American English or the standard of British English rather than to be thought with the non-native variety of English (Table 7). Not to mention, they understand the importance of having clear and intelligible pronunciation (table 8).

Table 7. Preference to be taught a non-native variety of English

\begin{tabular}{|c|c|c|c|c|c|}
\hline & & Frequency & Percent & $\begin{array}{c}\text { Valid } \\
\text { Percent }\end{array}$ & $\begin{array}{c}\text { Cumulative } \\
\text { Percent }\end{array}$ \\
\hline \multirow[t]{3}{*}{ Valid } & Yes & 3 & 4.5 & 4.6 & 4.6 \\
\hline & No & 62 & 92.5 & 95.4 & 100.0 \\
\hline & Total & 65 & 97.0 & 100.0 & \\
\hline Missing & System & 2 & 3.0 & & \\
\hline Total & & 67 & 100.0 & & \\
\hline
\end{tabular}

A number of students indicated their willingness to have more native varieties of English both in the contexts of standard British English such as Cockney, Scottish, Geordie, 
Yorkshire, Scouse, Welsh, Brummie dialects or in the contexts of standard American English such as Northern, Midland, Western, and Southern dialects $(\mathrm{N}=62 ; 95.4 \%)$ rather to know the outer or expanding circles of English $(\mathrm{N}=3 ; 4.6 \%)$. This preference is to attain clear and proper English pronunciation (table 8) and the pronunciation teaching should aim to help students' acquiring native-like pronunciation (table 9).

Table 8. Importance of having clear and intelligible pronunciation

\begin{tabular}{ll|r|r|r|r} 
& & & Valid & Cumulative \\
& Frequency & Percent & Percent & Percent \\
\hline Valid & Very important & 37 & 55.2 & 56.9 & 43.1 \\
\cline { 2 - 5 } & Important & 28 & 41.8 & 43.1 & 100.0 \\
\cline { 2 - 4 } & Total & 65 & 97.0 & 100.0 & \\
\hline Missing & System & 2 & 3.0 & & \\
\hline Total & & 67 & 100.0 & & \\
\hline
\end{tabular}

As students argue, it is critical to learn to pronounce within the intelligible pronunciation $(\mathrm{N}=65 ; 100 \%)$. Within the three options, none answered 'not important' option and they presumably had similar assumption by answering very important $(\mathrm{N}=37 ; 56.9 \%)$ and important $(\mathrm{N}=28 ; 43.1 \%)$. Since English entails 24 consonants with 15 short vowels, 5 long vowels, and 8 diphthongs, and 5 triphthongs, EFL learners need to understand their articulators and its distribution pattern to produce the acceptable pronunciation.

\begin{tabular}{ll|r|r|r|r}
\multicolumn{1}{l}{ Table 9. Goals of pronunciation teaching to help students as native-like } \\
& & Valid & Cumulative \\
& & Frequency & Percent & Percent & Percent \\
\hline Valid & Very important & 57 & 85.1 & 87.7 & 87.7 \\
\cline { 2 - 6 } & Important & 8 & 11.9 & 12.3 & 100.0 \\
\cline { 2 - 6 } & Total & 65 & 97.0 & 100.0 & \\
\hline Missing & System & 2 & 3.0 & & \\
\hline Total & & 67 & 100.0 & & \\
\hline
\end{tabular}

Table 9 discusses the students' perception of the importance of having pronunciation as native-like. Most students agreed upon the significance of teaching pronunciation on the standard American English and standard British English $(\mathrm{N}=57 ; 87.7 \%)$. As they consented, English pronunciation distinguishes words and meanings. By understanding the proper and intelligible pronunciation practice, they may have better confidence and speaking skills.

This ultimate goal for attaining native-like preference leads students to be contingent to teachers (table 10) and the use of pronunciation course (table 11). It could be defined that they are expecting to have the explicit input in the classroom rather than acquiring from their digital environment. 
Table 10. Preference for ideal pronunciation teacher

\begin{tabular}{llr|r|r|r} 
& & Frequency & Percent & $\begin{array}{c}\text { Valid } \\
\text { Percent }\end{array}$ & $\begin{array}{c}\text { Cumulative } \\
\text { Percent }\end{array}$ \\
\hline Valid & $\begin{array}{l}\text { The native speaker from } \\
\text { England or America }\end{array}$ & 54 & 80.6 & 83.1 & 83.1 \\
& A successful bilingual teacher & 11 & 16.4 & 16.9 & 100.0 \\
\cline { 2 - 7 } & Total & 65 & 97.0 & 100.0 & \\
\hline Missing & System & 2 & 3.0 & & \\
\hline Total & & 67 & 100.0 & & \\
\hline
\end{tabular}

Students expect to have the native speakers as the pronunciation teachers either from England for standard British English or from America for standard American English $(\mathrm{N}=54$; $83.1 \%$ ). With that, they believe they would reach the native-like level. While, some students do not refuse to have a successful bilingual teacher to teach $(\mathrm{N}=11 ; 16.9 \%)$.

Table 11. Preference for conversation or pronunciation course book

\begin{tabular}{llr|r|r|r} 
& & & Valid & Cumulative \\
& Frequency & Percent & Percent & Percent \\
\hline Valid & Native and native & 53 & 79.1 & 81.5 & 81.5 \\
\cline { 2 - 6 } & Native and non-native & 12 & 17.9 & 18.5 & 100.0 \\
\cline { 2 - 6 } & Total & 65 & 97.0 & 100.0 & \\
\hline Missing & System & 2 & 3.0 & & \\
\hline Total & & 67 & 100.0 & & \\
\hline
\end{tabular}

With the varied ability, students prefer to have a native pronunciation coursebook $(\mathrm{N}=53$; $81.5 \%)$ rather using the combination $(\mathrm{N}=12 ; 18.5 \%)$. The use of native book might help the students to have proper exposure even though it would be challenging to comprehend the book. While, the use of combination native and non-native pronunciation coursebook works well for the knowledge construction.

As the initial stage in design-based research, the conducted study was able to elicit students' and teachers' attitudes toward L2 pronunciation. The participants were aware of their limited exposure to the native English environment, but they expected to construe better phonological awareness. It may be presumed that they anticipate learning and acquiring more knowledge on how to pronounce the words properly. The result of the questionnaire was adequate to draw an assumption that it is needed an applicable tool to help them evaluate their pronunciation to improve their pronunciation as one of the components in speaking skills or communicative competence. The findings that had been explored in this study would be used for formulating and designing the assessment tool namely, O’Speak.

\section{CONCLUSION}

This study was the preliminary study in the proposed design-based research. This study was able to elicit the EFL learners' and teachers' attitudes toward the Standard English pronunciation. This study reports the practical problems in producing intelligible pronunciation as shown from the observation and the questionnaire. The positive language attitude towards English is seen from their willingness to acquire native-like pronunciation and better phonological awareness, although they were aware that they have limited exposure to standard British or American English. They anticipate learning and acquiring more knowledge on how to pronounce the words properly. The study was ample to draw a 
conclusion for designing an evaluation tool that they may use to assess and help them improve their pronunciation as one of the micro-skills in speaking skills or communicative competence. In a nutshell, this study suggests formulating and designing a proper assessment tool for their learning, which later called O’Speak.

\section{ACKNOWLEDGMENTS}

The authors would like to thank the Ministry of Research, Technology and Higher Education of the Republic of Indonesian (Ristekdikti) for the financial support of the Young Lecturer and Researcher Grant.

\section{REFERENCES}

[1] A. Kukulska-Hulme and L. Shield, "An overview of mobile assisted language learning: From content delivery to supported collaboration and interaction," $\operatorname{ReCALL}$, vol. 20, no. 3, pp. 271-289, 2008.

[2] R. Asmara, W. Asmara, A. Wulansari, M. Munirah, and H. Hersulastuti, "Measuring the Effect of A Flipped Classroom Model on Critical Thinking Skills," Proc. 2nd Work. Lang. Lit. Soc. Educ., 2019.

[3] J. C. Alderson, "Technology in testing: The present and the future," System, vol. 28, no. 4, pp. 593-603, 2000.

[4] J. C. Alderson, "Test of English as a Foreign Language ${ }^{\mathrm{TM}}$ : Internet-based Test (TOEFL iBT®)," Lang. Test., vol. 26, no. 4, pp. 621-631, 2009.

[5] L. Wang, D. Eignor, and M. K. Enright, A final analysis. 2011.

[6] K. M. Bailey, "Practical English Language Teaching: Speaking," McGraw-Hill ESL/ELT, 2005.

[7] Z. Xin, "From communicative competence to communicative language teaching," Int. J. English Linguist., vol. 8, no. 2, p. 163, 2017.

[8] L. Harding, "Communicative language testing: Current issues and future research," Lang. Assess. Q., vol. 11, no. 2, pp. 186-197, 2014.

[9] C. Clapham and T. McNamara, "Measuring Second Language Performance," TESOL $Q$. , vol. 34, no. 2, p. 376, 2000.

[10] L. Davis, "The influence of training and experience on rater performance in scoring spoken language," Lang. Test., vol. 33, no. 1, pp. 117-135, 2016.

[11] J. Wang, J. Napier, D. Goswell, and A. Carmichael, "The design and application of rubrics to assess signed language interpreting performance," Interpret. Transl. Train., vol. 9, no. 1, pp. 83-103, 2015.

[12] D. Klassen, R. Feuerstein, Y. Rand, and M. B. Hoffman, "The Dynamic Assessment of Retarded Performers," Can. J. Educ. / Rev. Can. l'éducation, vol. 6, no. 3, p. 117, 1981.

[13] A. Shay, "Mediated Learning Experience: Choosing Cognitive Modifiability," Psychol. Behav. Sci. Int. J., vol. 2, no. 2, 2017.

[14] E. B. Isman and D. Tzuriel, "The mediated learning experience (MLE) in a three generational perspective," Br. J. Dev. Psychol., 2008.

[15] C. S. Lidz, "Mediated Learning Experience (MLE) as a basis for an alternative approach to assessment," Sch. Psychol. Int., 2002.

[16] A. van Leeuwen and J. Janssen, "A systematic review of teacher guidance during collaborative learning in primary and secondary education," Educational Research 
Review, vol. 27. pp. 71-89, 2019.

[17] W. R. Kusumaningrum and P. Ferri Karma, "The Integration of Dynamic Assessment in L2 Classroom: How Students Perceive it?," Vis. J. Lang. Foreign Lang. Learn., vol. 7, no. 2, p. 132, 2018.

[18] D. Tzuriel, "Mediated Learning Experience and Cognitive Modifiability," J. Cogn. Educ. Psychol., vol. 12, no. 1, pp. 59-80, 2013.

[19] C. Reeves, Thomas, "Design research from a technology perspective," in Educational design research, 2006, pp. 52-66.

[20] T. Anderson and J. Shattuck, "Design-based research: A decade of progress in education research?," Educ. Res., vol. 41, no. 1, pp. 16-25, 2012.

[21] H. Heflin, J. Shewmaker, and J. Nguyen, "Impact of mobile technology on student attitudes, engagement, and learning," Comput. Educ., vol. 107, pp. 91-99, 2017.

[22] A. Coskun, "Future English Teachers' Attitudes towards EIL Pronunciation.," Online Submiss., vol. 6, no. 2, pp. 46-68, 2011. 